\title{
A NEW GENUS AND SPECIES OF AQUATIC CAVE-LIVING SNAIL FROM TASMANIA (MOLLUSCA: GASTROPODA: HYDROBIIDAE)
}

\author{
by W.F.Ponder
}

(with one table, three text-figures and one plate)

\begin{abstract}
PONDER, W.F., 1992 (31:x): A new genus and species of aquatic cave-living snail from Tasmania (Mollusca: Gastropoda: Hydrobiidae). Pap. Proc. R. Soc. Tasm. 126: 23-28. https://doi.org/10.26749/rstpp.126.23 ISSN 0080-4703. Australian Museum, PO Box A285, Sydney South, NSW, Australia 2000.
\end{abstract}

A new species and genus of hydrobiid snail, Pseudotricula eberhardi, is described from caves at Precipitous Bluff, southwestern Tasmania. This is the first description of a subterranean mollusc from Australia.

Key Words: cave-living, snail, aquatic, Tasmania.

\section{INTRODUCTION}

Although there are cave-dwelling hydrobiid snails known from many parts of the world, none have been described from Australia, although several species are known from New Zealand (Ponder 1966; Climo 1974, 1977). Recently several collections made by Stefan Eberhard in Tasmanian caves have been made available to the writer. All of the material is undescribed and most are species that are similar to, or, in some cases, the same as surface taxa. One species, however, is very unusual, being unlike any taxon known from Australasia, and is described herein.

This report forms a minor part of a survey of the hydrobiid taxa of Australia. Other work currently in preparation will deal in more detail with the relationships of this taxon.

\section{METHODS}

Standard methods were employed to mount material for scanningelectron microscope examination and for dissection (Ponder et al. 1989). Material was fixed in formalin in the field and then transferred to ethanol. Shells were measured using a digitisingpad linked to a microcomputer, as described by Ponder et al. (1989). Ten of the measured specimens were then sexed after dissolving the shells with dilute hydrochloric acid. Anatomical investigation was carried out on seven of the measured specimens, using a stereoscopic microscope with thespecimens being dissected on a black wax background in dilute Bouin's fluid. Material is housed in the Australian Museum, Sydney (AMS) and the Tasmanian Museum, Hobart (TM).

\section{TAXONOMY}

\section{Pseudotricula n. gen.}

Type species

Pseudotricula eberhardi n.sp.

\section{Etymology}

Named for the close resemblance of the shell to the Asian genus Neotricula (Pomatiopsidae).
Diagnosis

Shell (pl.1A) broadly conical, aperture with reflected outer lip, non-umbilicate. Protoconch (pl.1C, D) paucispiral, minutely punctate. Operculum (pl.1B, F) thin, inner surface lacking white smear or pegs, with markedly eccentric nucleus. Head (fig. 1A) with rather short, bilobed snout with scattered lateral cilia; cephalic tentacles long, tapering and appear to lack well-developed cilial bands; eyes (fig. 1A; e) small, pigmented, at outer bases of tentacles. Radula (pl.1G, H) with 2 (or rarely 3 ) pairs of small basal cusps on central teeth, outermost smallest. Pallial edge (fig. 1B; pe) thick, simple (i.e. no pallial tentacle). Ctenidium (fig. $1 \mathrm{~B} ; \mathrm{ct}$ ) short, confined toanteriortwo-thirds of cavity, with small, narrowly triangular filaments and with long, narrow efferent vessel (fig. 1B; ev) to pericardium. Osphradium (fig. 1B; os) small, oval, between posterior end and middle of ctenidium. Hypobranchial gland (fig. 1B; hg) lacking from anterior pallial roof, well developed posteriorly in narrow zone abutting rectum and also covering rectal coils. Rectum (fig. 1B; r) coiled in S-shape across posterior pallial roof; packed with oval faecal pellets. Anterior segment of rectum straight, on right side of cavity; anus (fig. 1B; a) set back slightly behind thickened part of mantle edge. Columellar muscle (fig. 1A; $\mathrm{cm}$ ) short and broad. Glandular pallial genital tract (fig. 1B; po) in posterior part of extreme right side of cavity. Renal organ extends partly into pallial roof (fig. $1 \mathrm{~B} ; \mathrm{rg}$ ). About half of length of pericardium (fig. 1B; pc) in pallial roof. Anterior alimentary canal typical of family. Stomach short, with large anterior gastric chamber, very small posterior chamber, single digestive gland opening and lacking posterior caecum. Male genital system with prostate gland (fig. 2C; pr) about half in pallial roof, kidney-shaped, approximately circular in section, pallial part with very thin ventral wall. Pallial vas deferens (figs 2C, 3A; pvd) opening mid-ventrally from pallial prostate gland, thin, non-muscular, straight or with slight undulations. Penis (fig. 3) with simple, long, tapering distal end; medial section simple, rather narrow, with straight to undulating penial duct; base expanded, with distinct transverse folds when at rest and undulating penial duct (fig. 3; pd). Female genital system with ovary short and simple; proximal coiled oviduct (fig. 2A; pco) simple Ushape, with U inclined anteriorly, not embedded in connective tissue, probably slightly muscular, surface firm and smooth; extends back to posterior end of bursa copulatrix; short and straight (fig. 2B; dco) distal to seminal receptacle. Coiled 
A

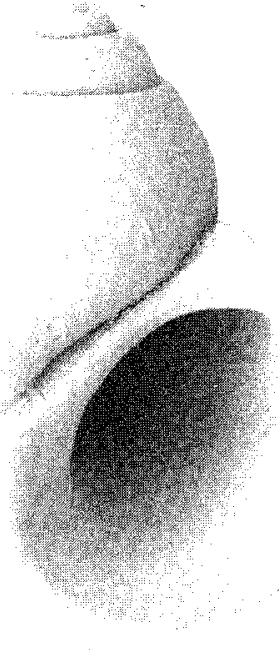

B
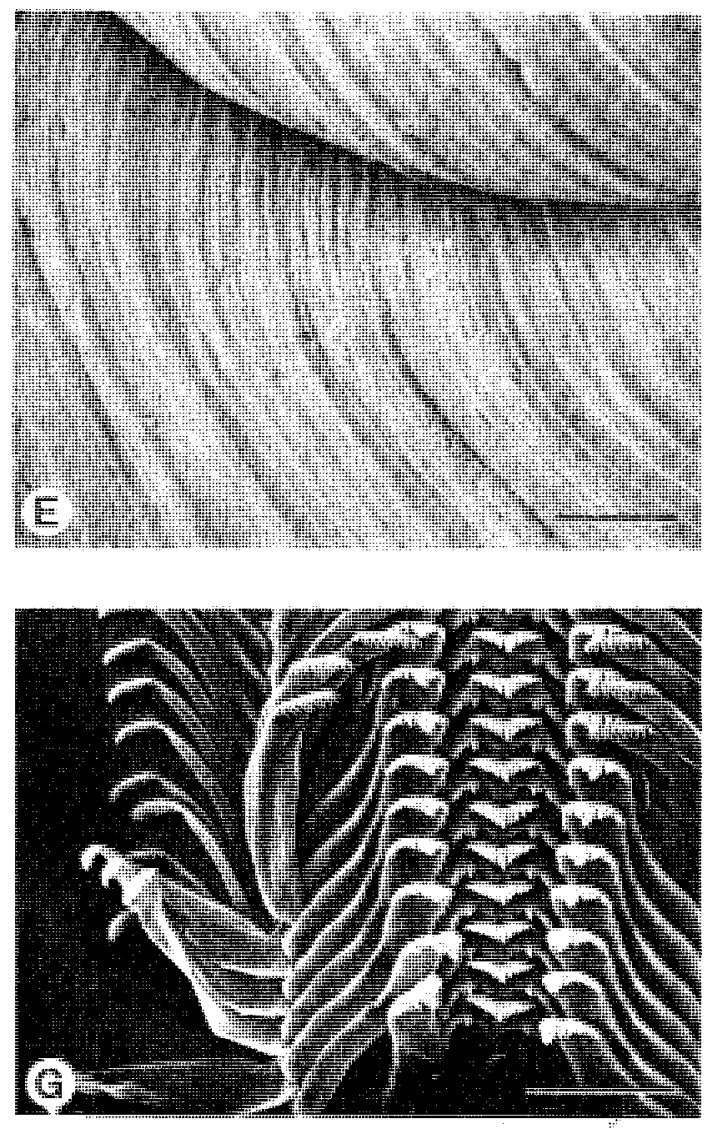
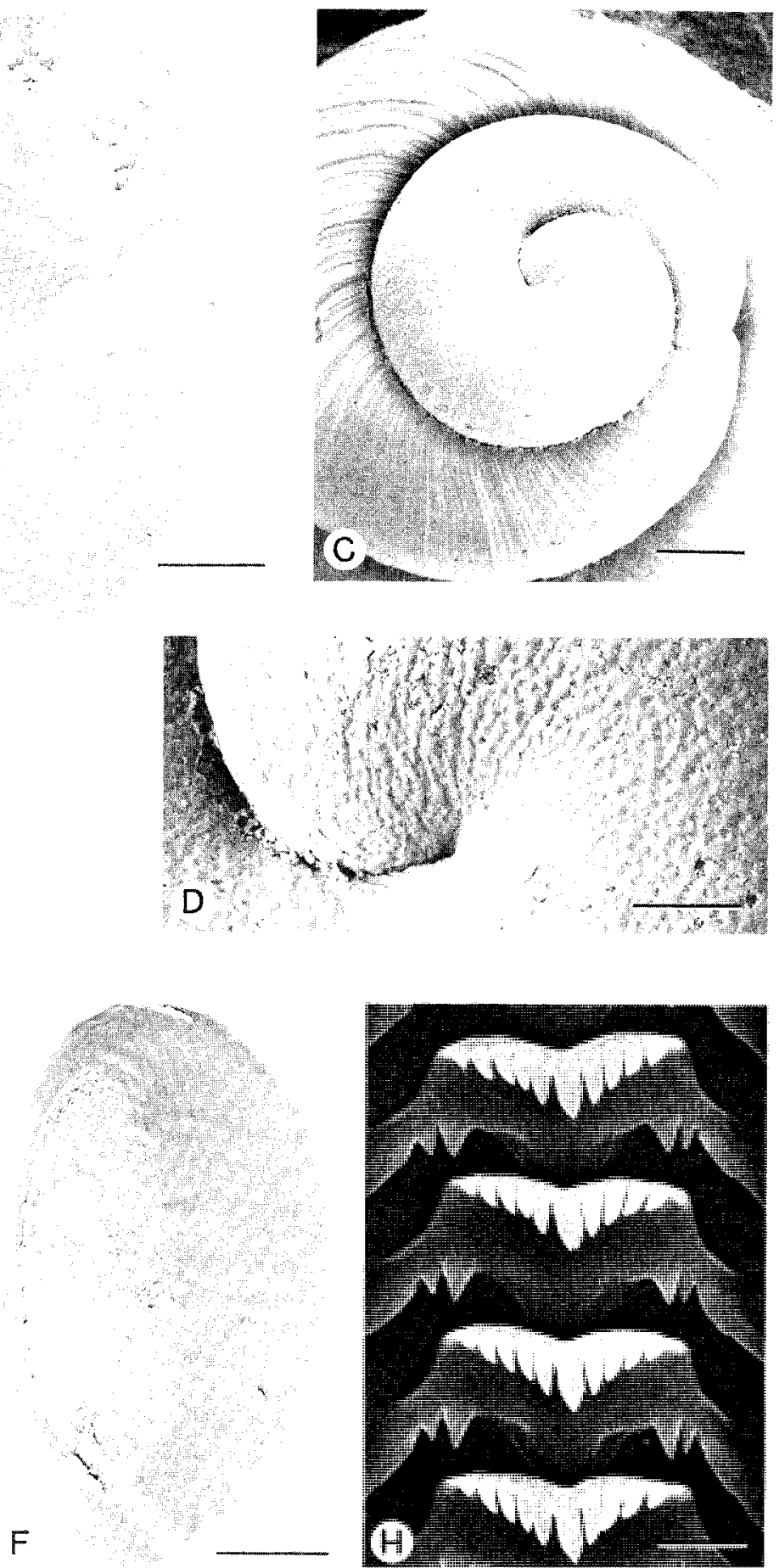

PLATE 1

(A) Shell (holotype). (B, F) Operculum (B, outer side, $F$, inner side). ( $C, D)$ Protoconch ( $D$, detail of microsculpture). (E) Detail of teleoconch microsculpture. $(G, H)$ Radula ( $H$, detail of central teeth). Scales: (A) $1 \mathrm{~mm},(B, F) 200 \mu \mathrm{m},(C) 100 \mu \mathrm{m}$, (D, G) $30 \mu \mathrm{m}$, (E) $50 \mu \mathrm{m}$, (H) $5 \mu \mathrm{m}$. 


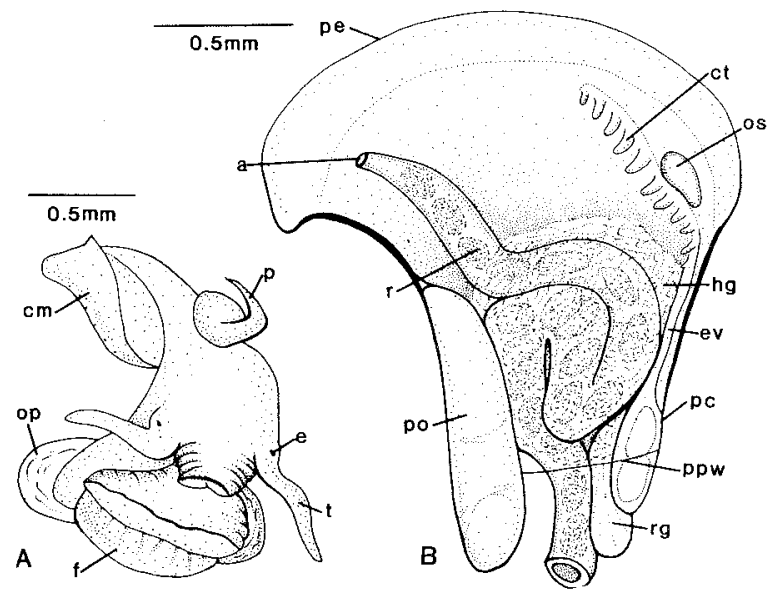

FIG. $1-$ - A ) Head-foot with the pallial roof and visceral coil removed. (B) Pallial roof viewed from inside.

$a$, anus; cm, columellar muscle; ct, ctenidium; $e$, eye; $e v$, efferent blood vessel; f, foot; hg, hypobranchial gland; op, operculum; os, osphradium; $p$, penis; $p c$, pericardium; pe, pallial edge; po, pallial oviduct; $p p w$, posterior pallial wall; $r$, rectum; rg, renal gland; $t$, cephalic tentacle.
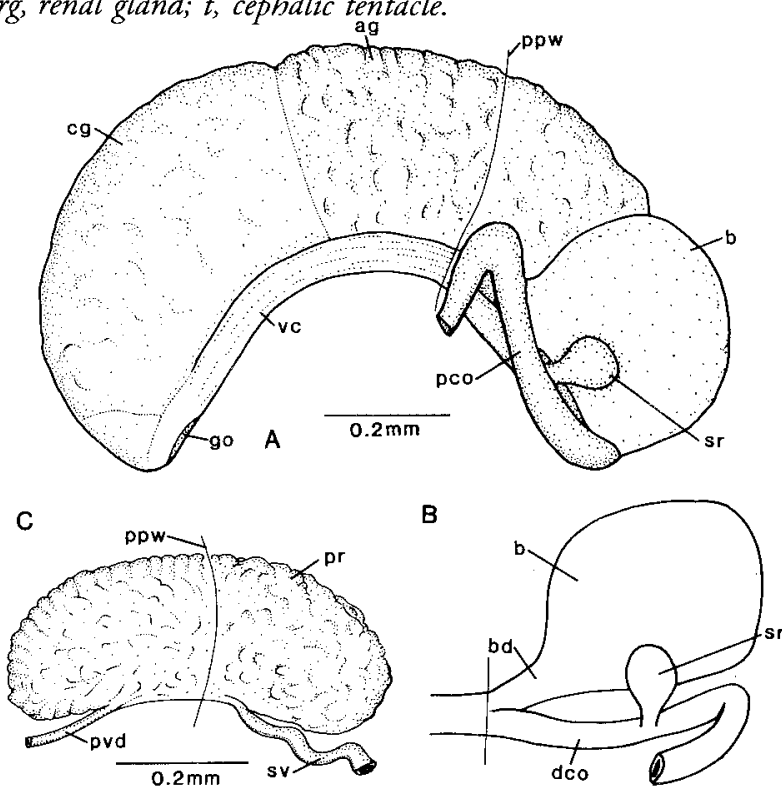

FIG. 3 - (A) Lateral view of female genital system viewed from the left side. (B) Diagram showing detail of posterior part of female genital system with the proximal part of the coiled oviduct removed. (C) Prostate gland viewed from the left side. $a g$, albumen gland; b, bursa copulatrix; bd, bursal duct; cg, capsule gland; dco, distal coiled oviduct; go, genital opening; pco, proximal coiled oviduct; pr, prostate gland; $p p w$, posterior pallial wall; pvd, pallial vas deferens; sr, seminal receptacle; sv, seminal vesicle; vc, ventral channel.

oviduct and bursal duct separate to posterior mantle wall (fig. 2B). Bursa copulatrix (fig. 2A,B; b) well behind posterior pallial wall; subglobular. Bursal duct (fig. 2B; bd) arises from antero-ventral side of bursa. Seminal receptacle (fig. 2B; sr) large, ovoid, slightly anterior to middle or at middle of left side of bursa. Two-thirds to about half of albumen gland (fig. $2 \mathrm{~A}$; ag) in front and half to one-third behind posterior pallial wall. Capsule gland (fig. 2A; cg) swollen, slightly wider than high, about equal to about two-thirds length of albumen gland. Ventral channel (fig. 2A; vc) simple; genital opening subterminal, small; capsule gland thin-walled in vicinity of opening. Anterior end of capsule gland well behind anus.
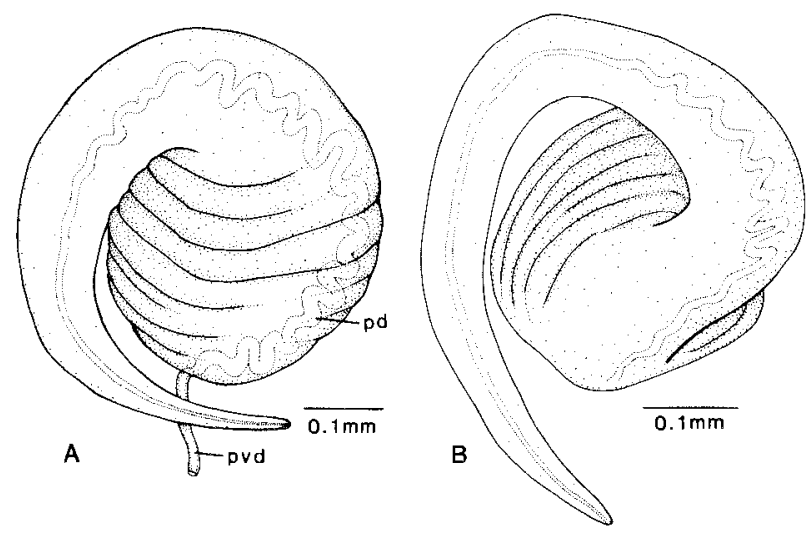

FIG. $2-(A, B)$ Penes, showing variation in the length of the distal part.

pd, penial duct; pvd, pallial vas deferens.

Nervous system with cerebral ganglia separated by long commissure slightly longer than length of ganglia; supraoesophageal ganglion small, separated from right pleural ganglion by connective about 5.7 to 8 times length of supraoesophageal ganglion; suboesophageal ganglion separated from left pleural ganglion by short connective, slightly longer than suboesophageal ganglion; pedal ganglia small, separated by very short commissure.

Additional details are given in the species description.

\section{Remarks}

This genus is named for its superficial similarity to the Asian pomatiopsid genus Neotricula Davis et al. 1986 (see Davis et al. 1976, fig. 3; as Tricula). It differs from all pomatiopsids in having a typical hydrobiid female reproductive system (see Davis 1979 for the distinguishing characters of both families).

The new genus differs from Beddomeia and other genusgroup names in that complex (including Phrantela) in having 2-3 (usually 2) pairs of denticles on the central teeth of the radula instead of one pair (Ponder $e t$ al., in press), in having the outer lip of the aperture thickened and reflected, and in lacking a gastric caecum. In addition, in nearly all of the Beddomeia-group taxa, the pallial vas deferens opens at the anterior end of the prostate gland and the seminal receptacle is adjacent to the posterior part of the bursa copulatrix. Most of the other named genera of Australasian hydrobiids have white material (often referred to as "calcareous", but see comment by Ponder et al. 1991) on the inner side of the operculum and three or more pairs of denticles on the central teeth. These genera include Fluvidona Iredale, 1937 (= Angrobia Iredale, 1943, Rivisessor Iredale, 1943 and Pupiphryx Iredale, 1943), Posticobia Iredale, 1943 and Tatea T. Woods, 1879 (Ponder et al. 1991) from Australia, and Potamopyrgus Stimpson, 1865 and allied genera from New Zealand (Climo 1974, 1977). Some genera in this group have only two pairs of denticles on the central teeth, including the New Caledonian Hemistomia and the Australian genera Fonscochlea (Ponder et al. 1989) and Jardinella (Ponder \& Clark 1990, Ponder, 1991). However, all members of this 
group differ from Pseudotricula in opercular characters (having pegs or a white smear), in not having a reflected outer lip and in the pallial vas deferens opening from the prostate gland at the posterior pallial wall, not between this wall and the anterior end of the prostate, as it does in Pseudotricula. Species of Trochidrobia (Ponder et al. 1989) are similar to Pseudotricula in having two pairs of denticles on the central teeth of the radula, but the shell is trochiform and the outer lip simple and thin in this genus, and it differs also in lacking a seminal receptacle.

None of the subterranean hydrobiids described from New Zealand have a shell like that of Pseudotricula, although that of species of Opacuincola is somewhat similar (Climo 1974: fig. 12A-F). That genus is characterised by a bifurcate penis and multiple pairs of denticles on the bases of the central teeth. Hadopyrgus is the only New Zealand genus with two pairs of basal denticles on the central teeth but has a pupiform shell and an operculum with a white smear on its inner surface. Additional details of the reproductive anatomy of both of these genera are not known.

\section{Pseudotricula eberhardi n. sp.}

Etymology

Named for Stefan Eberhard, Zoology Department, University of Tasmania, the collector of this and a number of other caveinhabiting hydrobiids.

\section{Holotype}

AMS C.165052. Small stream flowing in Cueva Blanca Cave, near Precipitous Bluff, Tasmania (map 1:25 000 series, Precipitous, 4618 662.5 855), 31 Mar. 1986, in turbulent, shallow streamway in dark zone, clinging to smooth rock. Coll.S. Eberhard. 4 paratypes AMS, C.165053, 1 paratype TM, 20151. Same locality, coll. S. Eberhard, 18 Dec. 1988. Very abundant in torrents and waterfalls in Black Curtains stream on smooth bedrock in deep cave zone approximately 150-200 $\mathrm{m}$ from entrance (c.120 paratypes AMS, C. 165054; 10 paratypes TM, 20152). Persephone Pot, Precipitous Bluff (map 1:25000 series, Precipitous, 4618665 855) in slowflowing stream with silty substrate in deep zone. Coll. S. Eberhard, 3 Jan. 1990 (2 adults and five juveniles, AMS, C.165055)

The Precipitous Bluff caves (approx. $43^{\circ} 27^{\prime} 51^{\prime \prime} S$, $146^{\circ} 36^{\prime} 51^{\prime \prime} \mathrm{E}$ ) were described and mapped by Eberhard \& Hume (1988), who also gave a list of the known fauna, and Hume (1989a, b, 1990).

Description (based on type material only)

Shell (pl.1A). Broadly conical, $2.51-3.01 \mathrm{~mm}$ in length; $1.87-2.26 \mathrm{~mm}$ in width; white to very pale yellow, periostracum thin, colourless. Protoconch (pl. 1C, D) of 1.5 whorls, microsculpture uniform, minutely punctate (pl.1D). Teleoconch of 2.25-2.5 convex whorls. Teleoconch sculpture of very fine, rather crisp, prosocline growth lines (pl.1C, E); periphery of body whorl evenly rounded. Inner lip moderately thickened, narrow, separated from parietal wall by shallow groove; columellar swelling absent. Outer lip prosocline, with strongly reflected lip, edge thin. Umbilical chink very narrow, $0.01-0.10 \mathrm{~mm}$ in width

Dimensions (table 1)

Operculum (pl. 1B, F). Thin, transparent, yellow.

Radula (pl. 1G, H). Radular sac extends beyond posterior end of buccal bulb for about same length as bulb but recurved dorsally into U-shape. Width from outer tip of lateral shaft to median cusp of central tooth in adult $45.5 \mu \mathrm{m}$. Central teeth (pl. $1 \mathrm{H})$ : dorsal edge with shallow indentations; five lateral cusps on each side, median cusp sharply pointed, longer than adjacent cusps; two (sometimes three) pairs of basal cusps not overlapping dorsal edge of next tooth; lateral edge thickened, at about $45^{\circ}$; mid-basal process wide, $U$ shaped. Lateral teeth: dorsal edge straight to lightly convex; ratio of length of dorsal edge to dorsal shaft about 0.43 ; basal projection bluntly pointed. Lateral median cusp longer than adjacent lateral cusps, three cusps on inner and four cusps on outer side. Inner marginal teeth with 15-17 cusps, outer marginal teeth with 14-20 cusps (two specimens examined).

Head-foot (fig. 1A). Animal unpigmented. Eyes small and black.

Mantle cavity (fig. 1B). Ctenidium (ct) narrow, with 9-13 filaments, only in anterior two-thirds of pallial cavity; filament apices on right. Osphradium (os) rather short, oval, slightly curved, wider in middle or at anterior end; anterior end opposite middle of ctenidium, about three filaments from posterior end. Efferent vessel (ev) nearly half length of ctenidium. Hypobranchial gland (hg) well developed, with smooth surface. Rectum (r) s-shaped, occupying much of mantle roof, covered by hypobranchial gland; faecal pellets mostly orientated longitudinally, some obliquely or transversely in coiled part. Renal organ with up to a quarter to (rarely) half of longitudinally orientated renal gland in mantle roof.

Male genital system (fig. 2C, 3). Testis occupies about one of two whorls behind stomach and overlaps posterior stomach for about 0.2 whorls. Seminal vesicle narrow, beneath about one-third of first whorl of testis behind stomach, coiled over stomach, with a few coils extending on to digestive gland behind stomach. Prostate gland (fig. 2C), penis (fig. 3) and other details described in generic diagnosis. Penis shows some variation in length of distal end (compare fig. 3A and B).

TABLE 1

\begin{tabular}{|c|c|c|c|c|c|c|c|c|}
\hline & $\mathrm{SL}^{*}$ & SW & AL & $\mathrm{AW}$ & BW & UM & $\mathrm{PD}$ & TW \\
\hline \multicolumn{9}{|c|}{ Holotype } \\
\hline Mean & 2.83 & 2.14 & 1.85 & 1.62 & 2.47 & 0.05 & 0.44 & 2.50 \\
\hline \multicolumn{9}{|c|}{ Topotypes ( 4 males) } \\
\hline Mean & 2.74 & 2.02 & 1.79 & 1.59 & 2.32 & 0.04 & 0.50 & 2.41 \\
\hline SD & 0.15 & 0.15 & 0.12 & 0.05 & 0.10 & 0.04 & 0.01 & 0.10 \\
\hline \multicolumn{9}{|c|}{ Topotypes ( 6 females) } \\
\hline Mean & 2.74 & 2.03 & 1.83 & 1.57 & 2.36 & 0.03 & 0.51 & 2.32 \\
\hline SD & 0.15 & 0.09 & 0.13 & 0.07 & 0.13 & 0.02 & 0.04 & 0.05 \\
\hline \multicolumn{9}{|c|}{ Unsexed paratype (1 specimen) } \\
\hline & 2.76 & 2.24 & 1.94 & 1.63 & 2.39 & 0.18 & 0.47 & 2.50 \\
\hline \multicolumn{9}{|c|}{ Persephone Pot (2 specimens) } \\
\hline Mean & 3.60 & 2.62 & 2.15 & 1.87 & 2.98 & 0.12 & 0.44 & 2.93 \\
\hline SD & 0.16 & 0.07 & 0.02 & 0.07 & 0.16 & 0.02 & 0.01 & 0.03 \\
\hline
\end{tabular}

* AL, aperture length; AW, aperture width; BW, length of body whorl; PD, protoconch diameter; SL, shell length; SW, shell width; TW, number of teleoconch whorls; UM, width of umbilicus. 
Female genital system (Fig. 2A, B). Ovary occupies 0.5-1.0 of about two whorls behind stomach. Other details given in generic diagnosis.

\section{Remarks}

This species is unlike any other taxon described from Australasia. Its short-spired shell superficially resembles some species of the Beddomeia group from which it can be readily distinguished by the distinctive reflected outer lip of the aperture as well as by the anatomical and radular differences outlined above.

This species has been recorded by Eberhard (in Eberhard \& Hume 1988) as "an unidentified species of aquatic snail ... adhering to smooth rock substrate in turbulent sections of the 'Black Curtains' streamway in Cueva Blanca. The shell and body of the snails are white. The snails were abundant and 8 specimens were collected". The specimens of a much larger series collected in December 1988 were fixed in improperly buffered formalin which resulted in serious deterioration of the shells and crystallisation of the neutralising agent in the animal tissues. Those from Persephone Pot are considerably larger than the type series (see dimensions above). However, the shells from the two populations are otherwise very similar and are almost certainly conspecific. The difference in size could be a phenotypic response to the slower-flowing water and/or the muddy sediment in the stream in Persephone Pot.

Pseudotricula lives sympatrically with an undescribed hydrobiid in Cueva Blanca Cave and with four other species of hydrobiid in Persephone Pot.

\section{DISCUSSION}

The existence of a distinctive taxon in a Tasmanian cave opens the possibility of other unique and possibly relict hydrobiid taxa being found in these habitats, as has been the case in some other invertebrate groups (e.g. the spider Hickmania [Forster et al. 1987], harvestmen [Hunt 1990], syncarid crustaceans [Lake \& Coleman 1977, Knott \& Lake 1980], and the coleopteran Idacarabus [Moore 1978]). However, a significant proportion of the caves in Tasmania have already been investigated (mainly by $S$. Eberhard) and, although a number of hydrobiid species have been found which appear to be restricted to (single?) cave systems, most, if not all, of these appear to belong to groups also found in surface waters.

Pseudotricula eberhardi appears to be an obligate cave dweller. It lives deep in the cave in which it is found clinging to smooth bedrock in swift-flowing water. The wide aperture seen in Pseudotricula is usually associated with this type of habit. The lack of body pigmentation is typical in cave-adapted taxa but the presence of pigmented eyes is not. Consequently, it is conceivable that Pseudotricula may not in fact be a long-time cave relict but may have adopted this habitat relatively recently. If this is the case, it is possible that related species may yet be found in surface habitats.

\section{ACKNOWLEDGEMENTS}

I gratefully acknowledge the assistance of Stefan Eberhard who collected and made available this species and much other cave material from Tasmania. Gerard Clark measured the specimens, and Anne Toluzzi and Geoff Avern prepared and photographed the material for examination with the SEM. Alison Miller assisted with plate preparation, and the final rendering of the drawings was done by Lisa Parkinson. This work was supported in large part by ARC grant A18831777. S. Eberhard and G.Hunt made valuable comments on the manuscript.

\section{REFERENCES}

Cumo, F.M., 1974: Description and affinities of the subterranean molluscan fauna of New Zealand. NZJ. Zool. 1(3): 247-284.

Cumo, F.M., 1977: Notes on the New Zealand hydrobiid fauna (Mollusca: Gastropoda: Hydrobiidae). J. R. Soc. NZ 7(1): $67-77$.

DAVIS, G. M., 1979: The origin and evolution of the gastropod family Pomatiopsidae, with emphasis on the Mekong River Triculinae. Acad. Nat. Sci. Phila., Mon. 20: i-vii, 1-120.

Davis, G.M., Kitikoon, V. \& Temcharoen, P., 1976: Monograph on "Lithoglyphopsis" aperta, the snail host of Mekong River schistosomiasis. Malacologia 15(2): 241-287.

Davis, G.M., SuUba RaO, N.V. \& Hogland, K.E., 1986: In search of Tricula (Gastropoda: Prosobranchia): Tricula defined, and a new genus described. Proc. Acad. Nat. Sci. Phila. 138(2): $426-442$.

Eberhard, S. \& Hume, N., 1988: Report of the Tasmanian Caverneering Club 1986 speleological reconnaissance expedition to Precipitous Bluff. Speleo Spiel, Newsl. Tasm. Cavern. Club 237: 1-19.

Forster, R.R, Platnick, N.I. \& GRAY, M.R., 1987: A review of the spider superfamilies Hypochiloidea and Austrochiloidea (Araneae, Araneomorphae). Bull. Am. Mus. Nat. Hist. 185(1): $1-116$.

Hume, N. (Ed.), 1989a: 1988/89 Precipitous Bluff Expeditionpart 1. Speleo Spiel, Newsl. Tasm. Cavern. Club 252: 1-12.

Hume, N. (Ed.), 1989b: 1988/89 Precipitous Bluff Expedition part 2. Speleo Spiel, Newsl. Tasm. Cavern. Club 253: 1-12.

Hume, N., 1990: 1989/1990 Precipitous Bluff Expedition — part I. Speleo Spiel, Newsl. Tasm. Cavern. Club 258: 1-12.

HuNT, G.S., 1990: Hickmanoxyomma, a new genus of cavernicolous harvestmen from Tasmania (Opiliones: Triaenonychidae). Rec. Aust. Mus. 42: 45-68.

KNOTT, B. \& LAKE, P.S., 1980: Eucrenonaspides oinotheke gen. et sp.n. (Psammaspididae) from Tasmania, and a new taxonomic scheme for Anaspidacea (Crustacea, Syncarida). Zool. Scrip. 9: 25-33.

LAKE, P.S. \& COLEMAN, D.J., 1977: On the subterranean syncarids of Tasmania. Helictite 15(1): 12-17.

MoORE, B.P., 1978: A new species of the Tasmanian cave carabid genus Idacarabus (Coleoptera). Aust. Entomol. Mag. 5(2): 23--25.

PONDER, W.F., 1966: On a subterranean snail and a tornid from New Zealand. J. Malacol. Soc. Aust. 10: 35-40.

PONDER, W.F. 1991: The eastern seaboard species of Jardinella (Mollusca, Gastropoda, Hydrobiidae), Queensland rainforest-inhabiting freshwater snails derived from the west. Rec. Aust. Mus. 43: 275-289. 
PONDER, W.F. \& CIARK, G.A., 1990: A radiation of hydrobiid snails in threatened artesian springs in western Queensland. Rec. Aust. Mus. 42: 301-363.

Ponder, W.F., Clark, G.A., Minler, A.C. \& Toluzzi, A., in press: On a major radiation of freshwater snails in Tasmania and eastern Victoria - a preliminary overview of the Beddomeia group (Mollusca: Gastropoda: Hydrobiidae).

Ponder, W.F., Colgian, D.G. \& Clark, G.A., 1991. The morphology, taxonomy and genetic structure of Tatea, estuarine snails from temperate Australia (Mollusca: Gastropoda: Hydrobiidae). Aust. J. Zool. 39: 447-497.

Ponder, W.F., Hershiler, R. \& Jfinkins, B., 1989. An endemic radiation of hydrobiid snails from artesian springs in northern South Australia: their taxonomy, physiology, distribution and anatomy. Malacologia 31(1): 1-140.

(accepted 9 August 1991) 